\title{
Optimalisasi Pemanfaatan Aplikasi SLiMS dalam Meningkatkan Kinerja Pustakawan pada Perpustakaan InstitutAgama Islam Negeri Curup
}

\author{
Rahmat Iswanto ${ }^{1}$,Eke Wince ${ }^{2}$, Marleni ${ }^{3}$ \\ ${ }^{1,2,3}$ Institut Tinggi Agama Islam Negeri (IAIN) Curup \\ ${ }^{1}$ e-mail:rahmatiswanto.database@gmail.com/rahmatiswanto \\ @iaincurup.ac.id \\ 2e-mail:ikewince.iw@gmail.com \\ 3e-mail:anak.nano3@gmail.com
}

\begin{abstract}
This paper is a theoretical study of the Optimization of the Use of SLiMS applications in improving the performance and creativity of librarians in a Library. By using the application SLiMS application many important jobs in the library that can be assisted include collections management, circulation service system, recording visit statistics, statistical collection records, database building and maintenance systems, evaluating the use of collections, and other tasks related to librarian assignments. Recording and evaluating the duties of librarians especially for the librarians of employees of AparaturSipil Negara (ASN) at the present time is carried out more carefully in accordance with the level and type of position. SLiMS applications are well designed to accommodate all librarian tasks according to the functions of the library.This research is to answers some questionsabout how the librarians work, how the SLiMS application in the library of Institut Agama Islam Negeri Curup apply, how the application of the SLiMS application in the library of Institut Agama Islam Negeri Curup optimize. The method used is a qualitative approach.
\end{abstract}

Keywords: library; automation; librarian; SLiMS

\begin{abstract}
Abstrak
Tulisan ini merupakan kajian teoritis mengenai Optimalisasi pemanfaatan aplikasi SLiMS dalam meningkatkan kinerja dan kreatifitas para pustakawan pada sebuah Perpustakaan. Semakin baik kinerja pustakawan, maka semakin baik pula penyelanggaraan perpustakaan. Dengan menggunakan aplikasi SLiMS aplikasi banyak pekerjaan penting dalam perpustakaan yang dapat dibantu antara lain pengelolaan koleksi, system pelayanan sirkulasi, pencatatan statistic kunjungan, pencatatan statistik koleksi, system pembangunan dan pemeliharan database, pengevaluasian keterpakaian
\end{abstract}


koleksi, dan tugas lain yang berkaitan dengan pustakawan. Pencatatan dan pengevaluasian tugas-tugas pustakawan khususnya bagi pustakawan pegawai aparatur sipil negara (ASN) pada saat sekarang dilakukan dengan lebih teliti sesuai dengan tingkatan dan jenis jabatannya. Aplikasi SLiMS memang dirancang dengan baik untuk mengakomodir seluruh tugas-tugas pustakawan sesuai dengan fungsi perpustakaannya. Penelitian ini menjawab pertanyaan bagaimana tugas pustakawan, bagaimana penerapan aplikasi SLiMS di perpustakaan IAIN Curup, bagaimana optimalisasi penerapan aplikasi SLiMS di perpustakaan IAIN Curup. Metode yang digunakan dengan pendekatan kualitatif.

Kata kunci: perpustakaan; otomasi; pustakawan; SLiMS

\section{A. PENDAHULUAN}

Perpustakaan Institut Agama Islam Negeri (IAIN) Curup menempatkan fungsinya sebagai lembaga penyedia sumber informasi untuk kegiatan tridharma perguruan tinggi sebagaimana perpustakaan perguruan tinggi lainnya. Dalam mengorganisasikan koleksi atau bahan pustaka, maupun elemen-elemen lainnya, perpustakaan senantiasa menjalankan sistem manajemen yang tepat. Perpustakaan harus dikelola dengan profesional agar mampu memenuhi kebutuhan pengguna. Pengaturan sumberdaya manusia dan sumberdaya lainnya dengan menempatkan tugas dan fungsimasingmasing.

Seiring dengan kemajuan teknologi, sistem manajemen dapat didukung oleh sebuah aplikasi sehingga proses manajemen dapat dilakukan dengan lebih efektif dan efesien. Aplikasi yang dikembangkan untuk menjalankan manajemen di perpustakaan juga dilakukan oleh para pengelola perpustakaan dan para ilmuan perpustakaan. Perpustakaan yang telah menggunakan komputer dan aplikasi dalam manajemennya disebut dengan perpustakaan yang terotomasi atau otomasi perpustakaan.

Dengan otomasi perpustakaan, fungsi perpustakaan sebagai lembaga penyedia sumber informasi untuk kegiatan tridharma perguruan tinggi akan semakin baik. Penggunaan aplikasi untuk menciptakan otomasi perpustakaan di Institut Agama Islam Negeri Curup telah dimulai dan dikembangkan sejak tahun 2007. Banyak pekerjaan penting dalam perpustakaan yang dapat dibantu oleh aplikasi ini antara lain pengelolaan koleksi, sistem pelayanan sirkulasi, pencatatan statistik kunjungan, pencatatan statistic koleksi, sistem pembangunan dan pemeliharan database, pengevaluasian keterpakaian koleksi, dan tugas lain yang berkaitan dengan pustakawan. 
Beberapa penelitian terdahulu dijadikan pembanding penelitian, antara lain:

1. Skripsi oleh Onny Cahyo Widodo (2016) yang berjudul Efektifitas penggunaan software open source (SLiMS) pada perpustakaan perguruan tinggi di Malang. Penelitian ini bertujuan untuk mengetahui efektifitas software open source (SLiMS), kendala yang dialami saat menggunakan SLiMS pada perpustakaan perguruan tinggi di Malang serta untuk memberikan masukan kepada developer atau komunitas SLiMS dalam mengembangkan software SLiMS. Metode penelitian menggunakan pendekatan deskriptif kuantitatif. Adapun hasil yang diperoleh sebagai berikut :1) Kualitas aplikasi SLiMS sudah memiliki sistem yang baik dan memadai serta memiliki kinerja yang cukup stabil untuk digunakan sebagai sistem informasi manajemen perpustakaan dan dapat mendukung kinerja Pustakawan sehingga pekerjaan menjadi lebih efektif dan efisien. 2) Aplikasi SLiMS dapat menampilkan informasi yang dibutuhkan penggunanya dengan ringkas dan jelas dengan kualitas informasi akurat dan tepat waktu. 3) Aplikasi SLiMS mudah dipelajari dan memiliki tingkat kegunaan yang sangat tinggi karena setiap fitur pekerjaan pengelolaan perpustakaan sudah disediakan pada software SLiMS. Dengan adanya SLiMS pekerjaan menjadi semakin cepat terselesaikan dan secara otomatis meningkatkan prestasi kerja penggunanya. 4) Kemampuan mengoperasikan komputer berdampak pada kelancaran dalam mengunakan aplikasi SLiMS sehingga dapat dapat dimanfaatkan secara maksimal. 5) SLiMS sudah digunakan sesuai dengan fungsinya, karena semua pengelolaan bahan pustaka di perpustakaan tidak bisa terlepas dari SLiMS. 6) Dengan aplikasi SLiMS pengelolaan perpustakaan dapat lebih ringan dan mudah sehingga meningkatkan kepuasan dan rasa nyaman pengguna. 7) Pemanfaatan aplikasi SLiMS akan lebih maksimal dan sesuai dengan kebutuhan, jika pengguna memiliki keterampilan pemrograman komputer.

2. Artikel ilmiah oleh Rex Fritz Sidupa (2016) berjudul Pengukuran Kinerja Aplikasi SLiMS pada Pelayanan Teknologi Informasi Menggunakan Framework ITIL v.3 (Studi Kasus: Perpustakaan dan Arsip Daerah Kota Salatiga). Pendekatan kuantitatif digunakan dalam metodologi penelitian ini. Tingkat kematangan yang didapat dalam penelitian di Persipda Kota Salatiga berada pada level defined (terdefinisi). Penggunaan aplikasi SLiMS sudah tepat dan sudah digunakan dengan baik. Tetapi pada level pengoptimalan atau optimized aplikasi SLiMS pada pelayanan masih sangat rendah dikarenakan tidak adanya bagian tenaga ahli khusus TI dalam mengetahui betul apa saja yang dibutuhkan aplikasi tersebut supaya bisa menjadi optimal. Aplikasi SLiMS sendiri secara kinerjanya dapat dinilai dalam penggunaanya 
selama ini, tergantung kepada staff atau pegawai yang menggunakannya dan mengembangkannya. Berjalannya baik atau buruknya sebuah aplikasi tergantung dari pihak organisasi atau perusahaan. Kenyataan yang di dapat dilapangan pegawai hanya bisa mengunakan aplikasi SLiMS tapi hanya beberapa orang saja yang mengetahui betul prinsip dan kebutuhan dari aplikasi tersebut. Persipda Kota Salatiga juga tidak memahami insiden dan masalah yang bisa saja terjadi sewaktu-waktu, serta tidak adanya pihak yang terkait untuk mengelola secara khusus pengembangan dari aplikasi SLiMS. Perlu dilakukan tindakan pencegahan atas masalah yang dapat timbul kapan saja sebagai salah satu cara untuk mencegah timbulnya masalah dengan melakukan analisa terhadap laporan kinerja. Seharusnya dilakukan sebuah survey kepada pengunjung tentang bagaimana proses pelayanan yang ada sekarang apakah costumer dimudahkan dalam proses pelayanan untuk mengethaui apa saja yang dibutuhkan dalam optimalisasi aplikasi SLiMS. Hal ini juga mengingatkan bahwa IT staff dalam sebuah organisasi sangat dibutuhkan untuk memenuhi sebuah tujuan yang melibatkan TI.

Pada penelitian terdahulu, aplikasi SLiMS dinilai dari keefektifitasan penggunaan aplikasi ini dan pada penelitian lain menganalisa dan mengukur keterpakaian aplikasi SLiMS. Sementara pada penelitian ini, peneliti mencoba memaparkan langka optimalisasi pemanfaatan aplikasi SLiMS khususnya bagi pustakawan dan perpustakaan IAIN Curup.

Pemanfaatan aplikasi SLiMS di perpustakaan Institut Agama Islam Negeri Curup dirasakan masih belum optimal karena pustakawan yang ada masih terbatas mengerjakan tugas-tugas pokok mereka. Hal ini dapat dievaluasi dan diperbaiki dengan melihat aplikasi SLiMS dengan lebih cermat untuk melihat "Bagaimana optimaliasi pemanfaatan aplikasi SLiMSuntuk meninggkatkan kinerja pustakawan pada perpustakaan Institut agama Islam Negeri Curup?. Maka dari itu penulis tertarik melakukan penelitian berjudul "Optimalisasi Pemanfaatan Aplikasi SLiMS dalam Meningkatkan kinerja pustakawan pada perpustakaan Institut agama Islam Negeri Curup". Dengan tujuan untuk mengetahui optimalisasi pemanfaatan aplikasi SLiMS dalam meningkatkan kinerja pustakawan pada perpustakaan Institut agama Islam Negeri Curup.

\section{B. HASIL DAN PEMBAHASAN}

\section{Pustakawan dan Tugas-tugasnya}

Profesi pustakawan merupakan pekerjaan profesional yang untuk melaksanakannya memerlukan persyaratan Pendidikan khusus di bidang ilmu 
perpustakaan dan informasi. Sementara menurut UUD RI Nomor 43 Tahun 2007, pustakawan adalah seseorang yang memiliki kompetensi yang diperoleh melalui pendidikan dan/atau pelatihan kepustakawanan serta mempunyai tugas dan tanggungjawab untuk melaksanakan pengelolaan dan pelayanan perpustakaan. (UUD RI Nomor 43 Tahun 2007).

Pustakawan adalah orang yang memberikan dan melaksanakan kegiatan perpustakaan dalam usaha pemberian layanan kepada masyarakat sesuai dengan visi dan misi Lembaga induknya. (Sulistiyo Basuki, 1993: 8).

Pustakawan mempunyai kewajiban untuk melakukan tindakan sesuai profesinya dan pustakawan harus dapat menghindari tindakan-tindakan yang bertentangan dengan norma-norma dalam masyarakat.

Profesi pustakawan di Indonesia secara resmi diakui berdasarkan SK MENPAN No.18/MENPAN/1988 dan diperbaharui dengan SK MENPAN No. 33/MENPAN/1990, yang kemudian diperkuat dengan keputusankeputusan lain yang berkaitan dengan kewajiban dan hak sebagai profesi dan fungsional pustakawan.

Dalam Peraturan Kepala Perpustakan Nasional Republik Indonesia Nomor 11 Tahun 2015 jabatan pustakawan terdiri dari 1. Pustakawan keterampilan, meliputi: pustakawan pelaksana, pustakawan pelaksana lanjutan dan pustakawan penyelia, 2. Pustakawan keahlian, meliputi: pustakawan ahli pertama, pustakawan ahli muda, pustakawan ahli madya dan pustakawan ahli utama.

Setiap jenjang jabatan pustakawan memiliki tugas pokok serta uraian kegiatan yang berbeda-beda, terdiri dari unsur utama dan unsur penunjang. Dimana unsur utama terdiri dari: a. Pendidikan b. Pengelolaan perpustakaan c. Pelayanan perpustakaan d. Pengembangan system kepustakawanan e. pengembangan profesi. Sedangkan unsur penunjang terdiri dari: a. Pengajaran dan pelatihan pada diklat fungsional/teknis bidang kepustakawanan b. Peran serta dalam seminar lokakarya/konfrensi di bidang kepustakawanan c. keanggotaan dalam organisasi profesi d. Keanggotaan dalam tim penilai e. Perolehan penghargaan/tandajasa f. Perolehan gelar/ijazah kesarjanaan lainnya.

\section{Aplikasi SLiMS}

(Ridho, M. Rasyid, 2012:5) Senayan Library Management System (SLiMS) adalah perangkat lunak system manajemen perpustakaan (library management system) dengan sumber terbuka yang dilisensikan di bawah GPL v3. 
Senayan Library Management System (SLiMS) adalah open source software (OSS) berbasis web untuk memenuhi kebutuhan automasi perpustakaan (library automation) skala kecil hingga skala besar. Dengan fitur dapat dikatakan, lengkap dan masih terus aktif dikembangkan, SLiMS dapat digunakan oleh perpustakaan yang memiliki jaringan local (intranet) maupun internet. Karena itu, SLiMS menggunakan Lisensi Publik GnU (GPL) v3 untuk menjamin kebebasan dalam mendapatkan, memodifikasi dan mendistribusikan kembali (rights to use, study, copy, modify, and redistribute computer programs). Pada saa titu, ketika masih disebut Senayan, versi 1 dan 2 tidak dirilis ke public karena masih tahap ujicoba dan sedang dalam penyempurnaan. Sejak (Senayan) versi 3, Senayan dianggap sudah stabil untuk dirilis ke public dan sudah waktunya diujicoba oleh komunitas pustakawan dan pengelola perpustakaan. Diharapkan dengan peer-to-peer review oleh publik, Senayan (SLiMS) semakin stabil dan fitur-fiturnya bias semakin beragam dan mengakomodasi banyak kebutuhan. Kunjungi Situs SLiMS untuk informasi lebih lanjut tentang SLiMS. (https://slims.web.id/web/pages/about/)

Aplikasi Senayan telah berkembang dengan pesat menyesuaikan dengan perkembangan teknologi dan informasi serta kebutuhan penggunanya. Aplikasi ini tidak hanya menampilkan data buku tapi juga dapatmenampilkan format gambar, suara, dan bahkanvidio. Aplikasi ini sangat fleksibel menunya dapat dirancang sesuai kebutuhan dan kondisi perpustakaan penggunanya. Dengan menggunakan aplikasi ini dapat mempercepat pekerjaan yang ada diperpustakaan. Sehingga pengelolaan manajemen dan system layanan pada sebuah perpustakaan dapat lebih efektif dan efisian.

\section{Fitur SLiMS}

Senayan library management system (SLiMS) memiliki banyak fitur yang akan membantu perpustakan dan pustakawan untuk melakukan pekerjaan mereka dengan mudah dan cepat. Berikut fitur yang disediakan oleh SLiMS:

- Online public access catalog (OPAC) dengan pembuatan thumbnail yang di-generate-on-the-fly. Thumbnail berguna untuk menampilkan sampul buku. Mode penelusuran tersedia dalam bentuk sederhana (simple search) dan tingkatlanjut (advced search).

- Detail record (cantuman) juga tersedia format XML (extensible markup language) untuk kebutuhan web service.

- Manajemen data bibliografi yang efisien meminimalisasi redundansi data. 
- Manajemen Masterfile untuk data referensial seperti GMD (general material designation), tipe koleksi, penerbit, pengarang, lokasi, supplier, dan lain-lain.

- Sirkulasidenganfitur :

$>$ Transaksi peminjaman dan pengembalian;

$>$ Reservasi koleksi;

$>$ Aturan peminjaman yang fleksibel;

$>$ Informasi keterlambatan dan denda.

- Manajemen keanggotaan

- Inventarisasi koleksi (stocktaking)

- Laporan dan statistic

- Pengelolaan terbitan berkala

- Dukungan pengelolaan dokumen digital multimedia (flv., mp3., pdf., dll.)

- SLiMS mendukung beragam format Bahasa termasuk bahasa yang tidak menggunakan penulisan latin. Menyediakan berbagai Bahasa pengantar (Indonesia, Inggris, Spanyol, arab, Jerman, Bengali, Persia, Melayu, PortugisBrasil, Thailand, Jepang, Urdu).

- Dukungan modul union catalog service sertanayanessebagai search proxy.

- Perhitungan pengunjung perpustakaan

- Member area untuk melihat koleksi sedang dipinjam oleh anggota, melakukan pemesanan peminjaman, ubah password pengguna, dll.

- Modul system denganfitur:

$>$ Konfigurasi system global;

$>$ Manajemenmodul;

$>$ Menajemenpengguna (gruppengguna dan penggunaaplikasi);

$>$ Pengaturanharilibur;

$>$ Pembuat barcode dan nomorpunggungotomatis;

$>$ Utilitasuntuk backup.

Dari uraian diatas dapat ditarik kesimpulan bahwa aplikasi SLiMS merupakan perangkat lunak yang mudah digunakan baik oleh pengelola perpustakaan maupun pemustaka dalam semua kegiatan perpustakaan. Beberapa manfaat yang dapat diperoleh dengan menggunakan aplikasi SLiMS dalam manajemen perpustakaan antara lain:

a. Meningkatkan Performa

Dengan menggunakan aplikasi SLiMS otomatis system layanan dan pengelolaan perpustakaan dikontrol oleh program komputer/software sehingga mengurangi adanya human error. Penelusuran informasi lebih mudah dan cepat. Pengelola perpustakaan juga dapat dengan muda 
mendapatkan informasi, statistic mengenai koleksi, pemustaka, kegiatan sirkulasi dan berbagai macam laporan lainya di dalam system SLiMS.

b. Peningkatan Produktivitas Kerja

Semakin produktivitasnya system pengelolaan dan layanan dengan dibantu aplikasi SLiMS, dengan waktu yang sama pekerjaan- pekerjaan pustakawan dalam mengolah koleksi meningkat, pemustaka yang dilayani lebih banyak. Sehingga pustakawan dapat melakukan lebih banyak pekerjaan yang menyebabkan meningkatnya kinerja pustakawan dan peningkatan kualitas layanan.

c. EfektifitasKerja

Kesalahan human error yang sering terjadi dapat diminimalisir oleh aplikasi SLiMS. Pemustaka juga lebih nyaman dan mudahdalammenggunakansemualayanan yang tersedia di perpustakaan.

d. Mempermudah Pekerjaan

Dengan penggunaan SLiMS pekerjaan yang dahulunya berat, butuh usaha dan prosesnya panjang dapat dipermudah dan disederhanakan oleh SLiMS. Sehingga Pengelolaan dan layanan dapat dilakukan dengan lebih mudah.

\section{Pustakawan IAIN Curup}

Pustakawan perpustakaan Institut Agama Islam Negeri Curup berjumlah enam orang. Mereka merupakan orang-orang yang memiliki kompetensi dan keterampilan di bidang kepustakawanan, serta mempunyai tugas dan tanggungjawan mengelola dan melakukan layanan di Perpustakaan Institut Agama Islam Negeri Curup. Jumlah pustakawan keahlian yang dimiliki sebanyak empat orang dan jumlah pustakawan keterampilan dua orang. Pustakawan keahlian yang dimiliki oleh perpustakaan Institut Agama Islam Negeri Curup tiga diantaranya berpendidikan strata dua (S2) atau magister di bidangi ilmu perpustakaan.

\section{Penerapan Aplikasi SLiMS oleh Pustakawan Institut Agama Islam Negeri Curup.}

Perpustakaan Institut Agama Islam Negeri Curup menerapkan Otomasi dari tahun 2007 tepatnya tanggal 7 - 10 Februari 2007, dengan menggunakan aplikasi SimPus dari program bantuan pusat dan dilanjutkan pembangunan pangkalan data selama kurang lebih 1 (satu) bulan. Awal bulan Maret tahun 2007 aplikasi SimPus mulai diiterapkan. Untuk meningkatkan lagi kualitas layanan pada tahun 2010 hingga sekarang, perpustakaan Institut Agama Islam Negeri Curup menerapkan program SLiMS (Senayan Library Management System). Aplikasi SLiMS memberikan kemudahan-kemudahan 
tidak hanya pada pencatatan dan evaluasi pustakawan, dengan aplikasi tersebut banyak bentuk pekerjaan kreativitas yang dapat dilakukan. Dalam meneliti penerapan aplikasi SLiMS pada perpustakaan IAIN Curup, peneliti melakukan penyebaran kegiatan pustakawan berdasarkan pendekatan berdasarkan rincian jenis kegiatan pustakawan menurut Peraturan Kepala Perpustakan Nasional Republik Indonesia Nomor 11 Tahun 2015 Tentang petunjuk teknis jabatan fungsional pustakawan dan angka kreditnya.

Seperti yang terterah pada Anak lampiran V-1 Peraturan Kepala Perpustakan Nasional Republik Indonesia Nomor 11 Tahun 2015 Tentang petunjuk teknis jabatan fungsional pustakawan dan angka kreditnya rincian kegiatan jabatan fungsional pustakawan keterampilan dan keahlian beserta angka kreditnya dapat dilihat pada table berikut:

Tabel 1

Rincian Kegiatan Pustakawan Berdasarkan Peraturan Kepala Perpustakan Nasional Republik Indonesia Nomor 11 Tahun 2015

\begin{tabular}{|c|c|c|}
\hline \multicolumn{2}{|r|}{ Kegiatan Pustakawan } & $\begin{array}{c}\text { Penerapan } \\
\text { SLiMS }\end{array}$ \\
\hline \multicolumn{3}{|c|}{$\begin{array}{l}\text { I. PENDIDIKAN } \\
\end{array}$} \\
\hline \multicolumn{2}{|r|}{ 1. PENDIDIKAN SEKOLAH DAN MEMPEROLEH GELAR/IJAZAH } & \\
\hline a. & Doktor/Spesialis II (S3) & Tidak \\
\hline b. & Pasca Sarjana/Spesialis I (S2) & Tidak \\
\hline c. & Sarjana (S1)/Diploma IV & Tidak \\
\hline d. & Sarjana Muda/Diploma III & Tidak \\
\hline e. & Diploma II & Tidak \\
\hline \multicolumn{3}{|c|}{ 2. PENDIDIKAN DAN PELATIHAN KEDINASAN KEPUSTAKAWANAN } \\
\hline a. & Lamanya lebih dari 960 jam & Tidak \\
\hline b. & Lamanya antara 641-960 jam & Tidak \\
\hline c. & Lamanya antara 481-640 jam & Tidak \\
\hline d. & Lamanya antara 161-480 jam & Tidak \\
\hline e. & Lamanya antara 81-160 jam & Tidak \\
\hline f. & Lamanya antara $30-80$ jam & Tidak \\
\hline \multicolumn{3}{|c|}{$\begin{array}{l}\text { II. PENGORGANISASIAN DAN PENDAYAGUNAAN KOLEKSI BAHAN PUSTAKA/SUMBER } \\
\text { INFORMASI }\end{array}$} \\
\hline \multicolumn{2}{|r|}{ 1. PENGEMBANGAN KOLEKSI } & \\
\hline \multirow[t]{4}{*}{ a. } & Menyusun Rencana Operasional & \\
\hline & Mengumpulkan data & Ya \\
\hline & Mengolah data & Tidak \\
\hline & Menganalisis dan menyusun rencana operasional & Tidak \\
\hline \multirow[t]{4}{*}{ b. } & Melakukan survai minat pemakai & \\
\hline & Membuat instrumen & Tidak \\
\hline & Mengumpulkan data & Ya \\
\hline & Mengolah dan Menganalisis data & Tidak \\
\hline c. & Membuat dan menyusun desiderata & \\
\hline \multirow[t]{5}{*}{ d. } & Menyeleksi bahan pustaka & \\
\hline & Menghimpun alat seleksi bahan pustaka & Tidak \\
\hline & Melakukan survai bahan pustaka & Ya \\
\hline & Meregistrasi bahan pustaka & $\mathrm{Ya}$ \\
\hline & Menyeleksi bahan pustaka & ya \\
\hline e. & Mengevaluasi dan menyiangi koleksi & \\
\hline
\end{tabular}


168 | Rahmat Iswanto, dkk : Optimalisasi Pemanfaatan Aplikasi...

\begin{tabular}{|c|c|c|}
\hline & Mengidentifikasi bahan pustaka & Ya \\
\hline & Menetapkan hasil evaluasi dan penyiangan & Tidak \\
\hline \multirow[t]{3}{*}{ f. } & Mengelola hasil penyiangan & \\
\hline & Mengidentifikasi bahan pustaka & Ya \\
\hline & Mengelola hasil penyiangan & Tidak \\
\hline \multicolumn{3}{|c|}{ 2. PENGOLAHAN BAHAN PUSTAKA } \\
\hline \multirow[t]{4}{*}{ a. } & Menyusun rencana operasional & \\
\hline & Mengumpulkan data & ya \\
\hline & Mengolah data & Tidak \\
\hline & Menganalisis dan Menyusun rencana operasional & Tidak \\
\hline b. & Melakukan verifikasi data bibliografi & ya \\
\hline \multirow[t]{3}{*}{ c. } & Melakukan katalogisasi & \\
\hline & Katalog sederhana & Ya \\
\hline & Katalog kompleks & $\mathrm{Ya}$ \\
\hline d. & Menentukan tajuk subyek & \\
\hline \multirow[t]{3}{*}{ e. } & Mengklasifikasi & \\
\hline & Melakukan klasifikasi yang bersifat sederhana & $\mathrm{Ya}$ \\
\hline & Melakukan klasifikasi yang bersifat kompleks & Ya \\
\hline f. & Menentukan kata kunci & Ya \\
\hline g. & Membuat anolasi & $\mathrm{Ya}$ \\
\hline \multirow[t]{3}{*}{ h. } & Mengalihkan data bibliografi & $\mathrm{Ya}$ \\
\hline & Manual & \\
\hline & Elektronis & $\mathrm{Ya}$ \\
\hline i. & Menyunting data bibliografi & Ya \\
\hline \multirow[t]{3}{*}{ j. } & Mengelola data bibliografi & Ya \\
\hline & Dalam bentuk kartu katalog & \\
\hline & Dalam bentuk basis data & \\
\hline $\mathrm{k}$. & Membuat kelengkapan pustaka & Ya \\
\hline 1. & Menyusun daftar tambahan pustaka & $\mathrm{Ya}$ \\
\hline $\mathrm{m}$. & Membuat sari karangan indikatif & Ya \\
\hline n. & Membuat sari karangan informatif & Ya \\
\hline o. & Menyusun bibliografi, indeks, dan sejenisnya & Tidak \\
\hline p. & Membuat kliping & Tidak \\
\hline \multicolumn{3}{|c|}{ 3. PENYIMPANAN DAN PELESTARIAN BAHAN PUSTAKA } \\
\hline \multirow[t]{4}{*}{ a. } & Menyusun rencana operasional & \\
\hline & Mengumpulkan data & $\mathrm{Ya}$ \\
\hline & Mengola data & Tidak \\
\hline & Menganalisis dan Menyususn rencana operasional & \\
\hline b. & Mengidentifikasi bahan pustaka & Ya \\
\hline c. & Mengelola jajaran bahan pustaka & Tidak \\
\hline \multirow[t]{3}{*}{ d. } & Merawat bahan pustaka & Tidak \\
\hline & Bersifat pencegahan/preventif & Tidak \\
\hline & Bersifat penanganan/treatment & Tidak \\
\hline \multirow[t]{3}{*}{ e. } & Memproduksi bahan pustaka & \\
\hline & Kepustakaan kelabu & \\
\hline & Tidak & Tidak \\
\hline \multicolumn{2}{|c|}{ 4. PELAYANAN INFORMASI } & Tidak \\
\hline \multirow[t]{4}{*}{ a. } & Menyusun rencana operasional & \\
\hline & Mengumpulkan data & $\mathrm{Ya}$ \\
\hline & Mengolah data & \\
\hline & Menganalisis dan Menyususn rencana operasional & \\
\hline b. & Melakukan layanan sirkulasi & $\mathrm{Ya}$ \\
\hline c. & Melakukan layanan perpustakaan keliling & \\
\hline \multirow[t]{3}{*}{ d. } & Melakukan layanan rujukan & \\
\hline & Bimbingan pemakaian sumber rujukan & $\mathrm{Ya}$ \\
\hline & Melakukan layanan rujukan cepat & Ya \\
\hline e. & Melakukan penelusuran literatur & \\
\hline
\end{tabular}




\begin{tabular}{|c|c|c|}
\hline & Untuk peneliti dan atau penulisan ilmiah & $\mathrm{Ya}$ \\
\hline & Untuk bahan bacaan & Ya \\
\hline f. & Melakukan layanan bahan pandang dengar (audio visual) & Tidak \\
\hline \multirow[t]{3}{*}{ g. } & Menyediakan bahan pustaka & \\
\hline & Koleksi setempat & Tidak \\
\hline & Melalui silang layan (kerja sama) & Tidak \\
\hline h. & Melakukan bimbingan membaca & Ya \\
\hline i. & Melakukan bimbingan pemakai perpustakaan & Ya \\
\hline j. & Melakukan cerita pada anak-anak & Tidak \\
\hline $\mathrm{k}$. & Membina kelompok membaca & Tidak \\
\hline \multirow[t]{3}{*}{1.} & Menyebarkan informasi terbaru & \\
\hline & Berbentuk lembar lepas & Tidak \\
\hline & Berbentuk paket informal & Tidak \\
\hline \multirow[t]{3}{*}{$\mathrm{m}$. } & Menyebarkan informasi terseleksi & \\
\hline & Berrbentuk lembar lepas & Tidak \\
\hline & Berbentuk paket informal & Tidak \\
\hline \multirow[t]{10}{*}{$\mathrm{n}}$. & Membuat analisis kepustakaan & \\
\hline & Berbentuk tinjauan (review) & Tidak \\
\hline & Penanggung jawab & Tidak \\
\hline & Penyusun & Tidak \\
\hline & $\begin{array}{ll} & \text { Mengumpulkan data }\end{array}$ & ya \\
\hline & Membuat analisis kepustakaan berbentuk resensi/tinjauan buku & \\
\hline & Berbentuk informasi teknis & \\
\hline & Penanggung jawab/editor & Tidak \\
\hline & Penyusun/penganalisis & Tidak \\
\hline & Mengumpul data & Ya \\
\hline \multirow[t]{3}{*}{ o. } & Statistik & \\
\hline & Mengumpul data & Ya \\
\hline & Mengolah dan menyusun data statistik & Tidak \\
\hline \multicolumn{3}{|c|}{ III. PEMASYARAKATAN PERPUSTAKAAN, DOKUMENTASI DAN INFORMAS } \\
\hline \multirow{5}{*}{ a. } & 1. PENYULUHAN & \\
\hline & Menyusun rencana operasional & \\
\hline & Mengumpulkan data & Tidak \\
\hline & Mengolah data & Tidak \\
\hline & Menganalisis dan menyusun rencana operasional & Tidak \\
\hline \multirow[t]{4}{*}{ b. } & Mengedentifikasi potensi wilayah & \\
\hline & Identifikasi wilayah & Tidak \\
\hline & Mengolah hasil identifikasi & Tidak \\
\hline & Menyusun program intervensi perkembangan perpusdokinfo & Tidak \\
\hline \multirow[t]{3}{*}{ c. } & Menyusun materi penyuluhan & \\
\hline & Tentang kegunaan dan pemanfaatan perpusdokinfo & Tidak \\
\hline & Tentang pengembangan perpusdokinfo & Tidak \\
\hline \multirow[t]{9}{*}{ d. } & Melaksanakan penyuluhan & \\
\hline & $\begin{array}{r}\text { Melakukan penyuluhan massal dengan cara memberikan penjelasan melalui TV } \\
\text { dan Radio }\end{array}$ & Tidak \\
\hline & Melakukan penyuluhan massal dengan cara menggunakan alat bantu audio visual & Tidak \\
\hline & Melakukan penyuluhan massal tanpa alat bantu & Tidak \\
\hline & Melakukan penyuluhan tatap muka dalam kelompok & Tidak \\
\hline & $\begin{array}{r}\text { Melakukan penyuluhan tentang pengembangan perpusdokinfo kepada } \\
\text { penyelenggara dan pengelola perpustakaan tingkat Nasional }\end{array}$ & Tidak \\
\hline & $\begin{array}{r}\text { Melakukan penyuluhan tentang pengembangan perpusdokinfo kepada } \\
\text { penyelenggara dan pengelola perpustakaan tingkat Propinsi }\end{array}$ & Tidak \\
\hline & $\begin{array}{r}\text { Melakukan penyuluhan tentang pengembangan perpusdokinfo kepada } \\
\text { penyelenggara dan pengelola perpustakaan tingkat Kabupaten }\end{array}$ & Tidak \\
\hline & $\begin{array}{r}\text { Melakukan penyuluhan tentang pengembangan perpusdokinfo kepada } \\
\text { penyelenggara dan pengelola perpustakaan tingkat kelompok }\end{array}$ & Tidak \\
\hline e. & Melakukan evaluasi paska penyuluhan & \\
\hline
\end{tabular}




\begin{tabular}{|c|c|c|}
\hline & Mengenai Kegunaan dan pemanfaatan perpusdokinfo tingkat Nasional & Tidak \\
\hline & Mengenai Kegunaan dan pemanfaatan perpusdokinfo tingkat Propinsi & Tidak \\
\hline & Mengenai Kegunaan dan pemanfaatan perpusdokinfo tingkat Kabupaten & Tidak \\
\hline & Mengenai pengembangan perpusdokinfo tingkat Nasional & Tidak \\
\hline & Mengenai pengembangan perpusdokinfo tingkat Propinsi & Tidak \\
\hline & Mengenai pengembangan perpusdokinfo tingkat Kabupaten & Tidak \\
\hline \multicolumn{3}{|c|}{ 2. PUBLISITAS } \\
\hline \multirow[t]{4}{*}{ a. } & Menyusun rencana operasional & \\
\hline & Mengumpul data & \\
\hline & Mengolah data & Tidak \\
\hline & Menganalisis dan menyusun rencana operasional & Tidak \\
\hline \multirow[t]{5}{*}{ b. } & Menyusun materi publisitas & \\
\hline & Menyusun materi publisitas berbentuk cerpen, skenario, artikel & Tidak \\
\hline & Menyusun materi publisitas berbentuk berita, synopsis, brosur, leaflet & Tidak \\
\hline & Menyusun materi publisitas berbentuk poster/gambar peraga & Tidak \\
\hline & Menyusun materi publisitas berbentuk slide, pandang dengar (audio visual) & Tidak \\
\hline c. & Melakukan publisitas & Tidak \\
\hline d. & Melakukan evaluasi paska publisitas & Tidak \\
\hline \multicolumn{3}{|c|}{ 3. PAMERAN } \\
\hline \multirow[t]{4}{*}{ a. } & Menyusun rencana operasional pameran & \\
\hline & Mengumpul data & Tidak \\
\hline & Mengolah data & Tidak \\
\hline & Menganalisis dan menyusun rencana operasional & Tidak \\
\hline b. & Membuat rancangan desain pameran & Tidak \\
\hline c. & Menyiapkan materi dan penataan pameran & Tidak \\
\hline \multirow[t]{3}{*}{ d. } & Menyelenggarakan pameran & \\
\hline & Menjadi penanggung jawab dalam penyelenggaraan pameran & Tidak \\
\hline & Menjadi pemandu dalam penyelenggaraan pameran & Tidak \\
\hline d. & Melakukan evaluasi paska pameran & \\
\hline \multicolumn{3}{|c|}{ IV. PENGKAJIAN PENGEMBANGAN PERPUSTAKAN, DOKUMENTASI DAN INFORMASI } \\
\hline \multicolumn{3}{|c|}{\begin{tabular}{l|l} 
1. PENGKAJIAN & \\
\end{tabular}} \\
\hline \multirow[t]{4}{*}{ a. } & Menyusun rencana operasional & \\
\hline & Mengumpul data & Ya \\
\hline & Mengolah data & Tidak \\
\hline & Menganalisis dan menyusun rencana operasional & Tidak \\
\hline \multirow[t]{11}{*}{ b. } & Melakukan pengkajian & \\
\hline & Menyusun Instrumen untuk pengkajian yang bersifat sederhana & Tidak \\
\hline & Mengumpul data untuk pengkajian yang bersifat sederhana & Ya \\
\hline & Mengolah data untuk pengkajian yang bersifat sederhana & Tidak \\
\hline & Menganalisis dan merumuskan hasil kajian yang bersifat sederhana & Tidak \\
\hline & Mengevaluasi dan menyempurnakan hasil kajian yang bersifat sederhana & Tidak \\
\hline & Menyusun Instrumen untuk pengkajian yang bersifat kompleks & Tidak \\
\hline & Mengumpul data untuk pengkajian yang bersifat kompleks & ya \\
\hline & Mengolah data untuk pengkajian yang bersifat kompleks & Tidak \\
\hline & Menganalisis dan merumuskan hasil kajian yang bersifat kompleks & Tidak \\
\hline & Mengevaluasi dan menyempurnakan hasil kajian yang bersifat kompleks & Tidak \\
\hline \multicolumn{3}{|c|}{ 2. PENGEMBANGAN PERPUSTAKAAN } \\
\hline \multirow[t]{4}{*}{ a. } & Menyusun rencana operasional & \\
\hline & Mengumpul data hasil penelitian & \\
\hline & Mengolah data & Tidak \\
\hline & Menganalisis dan menyusun rencana operasional & Tidak \\
\hline \multirow[t]{5}{*}{ b. } & Membuat prototip/model & \\
\hline & Menyusun desain & Tidak \\
\hline & Membuat prototip/model & Tidak \\
\hline & Melakukan uji coba prototip/model & Tidak \\
\hline & Mengevaluasi dan menyempurnakan prototip/model & Tidak \\
\hline
\end{tabular}




\begin{tabular}{|c|c|c|}
\hline \multicolumn{3}{|c|}{ 3. ANALISIS/KRITIK KARYA KEPUSTAKAAN } \\
\hline & Menganalisis/kritik karya kepustakaan & Tidak \\
\hline & Menyempurnakan karya kepustakaan & Tidak \\
\hline \multicolumn{3}{|c|}{ 4. PENELAAHAN PENGEMBANGAN DI BIDANG PERPUSDOKINFO } \\
\hline \multicolumn{3}{|c|}{ V. PENGEMBANGAN PROFESI } \\
\hline \multicolumn{3}{|c|}{ 1. MEMBUAT KARYA TULIS/KARYA ILMIAH DI BIDANG PERPUSDOKINFO } \\
\hline \multirow[t]{3}{*}{ a. } & Karya tulis/ilmiah hasil penelitian yang dipublikasikan & \\
\hline & Dalam bentuk buku yang diterbitkan secara nasional & Tidak \\
\hline & Dalam bentuk makalah yang diakui oleh instansi & Tidak \\
\hline \multirow[t]{3}{*}{ b. } & $\begin{array}{l}\text { Karya tulis/ilmiah hasil penelitian yang tidak dipublikasikan tapi dipublikasikan } \\
\text { di perpustakaan }\end{array}$ & \\
\hline & $\begin{array}{ll} & \text { Dalam bentuk buku }\end{array}$ & Tidak \\
\hline & $\begin{array}{ll} & \text { Dalam bentuk makalah } \\
\end{array}$ & Tidak \\
\hline \multirow[t]{3}{*}{ c. } & Karya tulis/ilmiah hasil penelitian yang berupa tinjauan hasil gagasan sendiri & \\
\hline & Dalam bentuk buku yang diterbitkan secara nasional & Tidak \\
\hline & Dalam bentuk makalah yang diakui oleh instansi berwenang & Tidak \\
\hline d. & $\begin{array}{l}\text { Makalah berupa tinjauan ilmiah hasil uji coba di bidang perpusdokinfo yang tidak } \\
\text { dipublikasikan tapi didokumentasikan }\end{array}$ & Tidak \\
\hline e. & $\begin{array}{l}\text { Karya tulis populer di bidang perpusdokinfo setiap tulisan yang merupakan satu } \\
\text { kesatuan yang dipublikasikan melalui media massa }\end{array}$ & Tidak \\
\hline \multicolumn{3}{|c|}{ 2. MENYUSUN PEDOMAN/PETUNJUK TEKNIS PERPUSDOKINFO } \\
\hline a. & Yang disampaikan dalam pertemuan ilmiah, diklat, dan sejenisnya & Tidak \\
\hline b. & Menyusun pedoman standar yang diakui Perpusnas dan diedarkan secara nasional & Tidak \\
\hline & Menyusun pedoman umum teknis perpusdokinfo & Tidak \\
\hline \multicolumn{3}{|c|}{$\begin{array}{l}\text { 3. MENTERJEMAHKAN/MENYADUR BUKU DAN BAHAN-BAHAN LAIN DI } \\
\text { BIDANG PERPUSDOKINFO }\end{array}$} \\
\hline a. & Berbentuk buku yang dipublikasikan secara nasional & Tidak \\
\hline b. & Berbentuk makalah yang diakui instansi berwenang & Tidak \\
\hline \multicolumn{3}{|c|}{$\begin{array}{l}\text { 4. MELAKUKAN TUGAS SEBAGAI KETUA KELOMPOK/KOORDINATOR } \\
\text { PUSTAKAWAN ATAU MEMIMPIN UNIT PERPUSTAKAAN }\end{array}$} \\
\hline a. & Sebagai ketua kelompok/koordinator pustakawan & Tidak \\
\hline \multirow[t]{3}{*}{ b. } & Sebagai Pimpinan/Ketua unit perpustakaan & \\
\hline & Eselon I, II atau yang sejajar & Tidak \\
\hline & Eselon III ke bawah atau yang sejajar & Tidak \\
\hline \multicolumn{2}{|r|}{ 5. MENYUSUN KUMPULAN TULISAN UNTUK DIPUBLIKASIKAN } & Tidak \\
\hline \multicolumn{3}{|c|}{$\begin{array}{l}\text { 6. MEMBERIKAN KONSULTASI KEPUSTAKAWANAN YANG BERSIFAT } \\
\text { KONSEP }\end{array}$} \\
\hline a. & Institusi & Tidak \\
\hline b. & Perorangan & Tidak \\
\hline \multicolumn{3}{|c|}{ VI. PENUNJANG KEGIATAN KEPUSTAKAWANAN } \\
\hline \multicolumn{3}{|c|}{ 1. MENGAJAR DI BIDANG PERPUSDOKINFO } \\
\hline \multirow[t]{3}{*}{ a. } & Mengajar di bidang perpusdokinfo pada pendidikan sekolah & \\
\hline & Tingkat Perguruan Tinggi & Tidak \\
\hline & Tingkat SLTA & Tidak \\
\hline b. & Mengajar di bidang perpusdokinfo pada pendidikan luar sekolah & Tidak \\
\hline \multicolumn{3}{|c|}{ 2. MELATIH DI BIDANG PERPUSDOKINFO } \\
\hline a. & Melatih siswa/mahasiswa & Tidak \\
\hline b. & Melatih petugas perpustakaan & Tidak \\
\hline \multicolumn{3}{|c|}{$\begin{array}{l}\text { 3. MEMBIMBING MAHASISWA MEMBUAT SKRIPSI/THESIS/DESERTASI DI } \\
\text { BIDANG PERPUSDOKINFO }\end{array}$} \\
\hline & $\begin{array}{ll} & \text { Mahasiswa S3 }\end{array}$ & Tidak \\
\hline & Mahasiswa S2 & Tidak \\
\hline & Mahasiswa S1/DIV & Tidak \\
\hline & $\begin{array}{ll} & \text { Mahasiswa DI s.d. DIII }\end{array}$ & Tidak \\
\hline \multicolumn{3}{|c|}{ 4. MEMBERIKAN KONSULTASI TEKNIS DI BIDANG PERPUSDOKINFO } \\
\hline & $\begin{array}{ll} & \text { Mahasiswa S3 } \\
\end{array}$ & Tidak \\
\hline & Mahasiswa S2 & Tidak \\
\hline
\end{tabular}


172 | Rahmat Iswanto, dkk : Optimalisasi Pemanfaatan Aplikasi...

\begin{tabular}{|c|c|c|}
\hline & Mahasiswa S1/DIV & Tidak \\
\hline & $\begin{array}{ll} & \text { Mahasiswa DI s.d. DIII } \\
\end{array}$ & Tidak \\
\hline \multicolumn{3}{|c|}{$\begin{array}{l}\text { 5. MENGIKUTI SEMINAR, LOKA KARYA, PERTEMUAN DAN SEJENISNYA DI } \\
\text { BIDANG PERPUSDOKINFO }\end{array}$} \\
\hline a. & Tingkat nasional/internasional sebagai pemrasaran & Tidak \\
\hline b. & Tingkat nasional/internasional sebagai moderator/narasumber & Tidak \\
\hline c. & Tingkat nasional/internasional sebagai peserta & Tidak \\
\hline \multicolumn{3}{|c|}{ 6. MENJADI ANGGOTA ORGANISASI PROFESI KEPUSTAKAWANAN } \\
\hline \multirow[t]{3}{*}{ a. } & Tingkat nasional/internasional & \\
\hline & Sebagai pengurus aktif & Tidak \\
\hline & Sebagai anggota aktif & Tidak \\
\hline \multirow[t]{3}{*}{ b. } & Tingkat Propinsi/Kabupaten/Kota & \\
\hline & Sebagai pengurus aktif & Tidak \\
\hline & Sebagai anggota aktif & Tidak \\
\hline \multicolumn{3}{|c|}{ 7. MELAKUKAN LOMBA KEPUSTAKAWANAN } \\
\hline a. & Penanggung jawab & Tidak \\
\hline b. & Dewan juri & Tidak \\
\hline c. & Penyelenggara & Tidak \\
\hline \multicolumn{3}{|c|}{ 8. MEMPEROLEH PENGHARGAAN/TANDA JASA } \\
\hline \multirow[t]{4}{*}{ a. } & Tanda kehormatan/Satyalencana & \\
\hline & Karya satya 30 tahun & Tidak \\
\hline & Karya satya 20 tahun & Tidak \\
\hline & Karya satya 10 tahun & Tidak \\
\hline b. & Gelar kehormatan akademis & \\
\hline \multicolumn{3}{|c|}{$\begin{array}{l}\text { 9. MEMPEROLEH GELAR KESARJANAAN YANG TIDAK SESUAI DENGAN } \\
\text { BIDANG }\end{array}$} \\
\hline & $\begin{array}{ll}2 & \text { Doktor }\end{array}$ & Tidak \\
\hline & Pasca Sarjana & Tidak \\
\hline & Sarjana & Tidak \\
\hline & Sarjana Muda/Diploma III & Tidak \\
\hline & Diploma II & Tidak \\
\hline $\begin{array}{l}10 . \\
\text { PER }\end{array}$ & $\begin{array}{l}\text { IENYUNTING RISALAH PERTEMUAN ILMIAH DI BIDANG } \\
\text { USDOKINFO }\end{array}$ & Tidak \\
\hline 11. & ERAN SERTA DALAM TIM PENILAI JABATAN PUSTAKAWAN & Ya \\
\hline
\end{tabular}

\section{Optimalisasi Pemanfaatan Aplikasi SLiMS dalam Meningkatkan Kinerja Pustakawan pada Institut Agama Islam Negeri Curup.}

Aplikasi SLiMS memang dirancang dengan baik untuk mengakomodir seluruh tugas-tugas pustakawan sesuai dengan fungsi perpustakaan agar perpustakaan dapat menjadi lembaga penting. Perpustakaan Institut Agama Islam Negeri Curup senantiasa dikembangkan untuk memberikan banyak manfaat bagi sivitas akademik dan memberikan fungsinya secara maksimal dan berkemajuan. Aplikasi SLiMS dapat dipakai untuk meningkatkan kinerja dan menciptakan kreatifitas para pustakawan.

Dengan otomasi semua kegiatan perpustakaan manual/tradisional berubah menjadi sistem komputerisasi. Untuk menunjang terlaksananya otomasi perpustakaan maka perpustakaan Institut Agama Islam Negeri Curup melengkapi semua komponen otomasi yang dibutuhkanantara lain: Pengguna (user), PerangkatKeras (hardware), PerangkatLunak (Software), Jaringan 
(Networking), Data, Manual atau Panduan, Internet dan Sistem Manajemn Informasi. Dari tahun 2010 - 2015 menggunakan Senayan Versi senayan3stable14, dari tahun 2016 - 2018 Senayan Version senayan 8- stable8, dari tahun 2018 - 2019 Senayan Version SLiMS 8.3.1 (Akasia).

Dalam menjalankan fungsinya tugas-tugas pokok di perpustakaan dilakukan oleh pustakawan. Dimana setiap jenjang memiliki uraian tugas yang berbeda-beda. Pada awal tahun setiap Pustakawan diharuskan merencanakan urain tugas yang akan dilakukan satu tahun kedepan yang tertuang dalam Sasaran Kerja Pegawai (SKP). Pencatatan dan pengevaluasian tugas-tugas Pustakawan khususnya bagi Pustakawan pegawai Aparatur Sipil Negara (ASN) pada saat sekarang dilakukan dengan lebih teliti sesuai dengan tingkatan dan jenis jabatannya.

Sebagai bentuk pertanggungjawaban sasaran kerja pegawai, maka setiap Pustakawan memberikan bukti fisik kegiatan yang telah direncanakan. Pekerjaan yang telah direncanakan memiliki banyak manfaat bagi pegawai sendiri, bagi pemustaka atau masyarakat pengguna perpustakaan, serta perwujudan eksistensi perpustakaan dengan fungsi-fungsinya.

Aplikasi SLiMS yang digunakan pada kegiatan perpustakaan Institut Agama Islam Negeri Curup khususnya untuk mencatat dan mengevaluasi tugas-tugas mereka memberikan kontribusi yang signifikan. Dengan pencatatan yang dilakukan oleh aplikasi, bukti fisik dapat ditunjukkan dengan mudah dan tepat. Melalui pencatatan yang tepat, hasil kinerja Pustakawan akan semakin mudah untuk dievaluasi.

Aplikasi SLiMS memberikan kemudahan-kemudahan tidak hanya pada pencatatan dan evaluasi Pustakawan, dengan aplikasi tersebut banyak bentuk pekerjaan kreativitas yang dapat dilakukan. Aplikasi SLiMS memang dirancang dengan baik untuk mengakomodir seluruh tugas-tugas Pustakawan, untuk memanfaatkan secara maksimal aplikasi SLiMSPustakawan dituntut untuk memiliki keterampilan mengoperasikan perangkat komputer. Sehingga aplikasi SLiMS dapat dipakai untuk meningkatkan kinerja dan menciptakan kreatifitas para Pustakawan.

Dari hasil identifikasi pada table peranan aplikasi SLiMS terhadap butir-butir kegiatan pustakawan berdasarkan Peraturan Kepala Perpustakan Nasional Republik Indonesia Nomor 11 Tahun 2015 dan dalam mengumpulkan data terkait penerapan aplikasi SLiMS dalam kegiatankegiatan tersebut, peneliti melakukan wawancara mendalam dengan panduan alat bantu wawancara yang berbentuk rincian kegiatan pustakawan. Sehingga 
secara rinci optimalisasi pemanfaatan aplikasi SLiMS pada setiap butir kegiatan pustakawan dapat dianalisis dan dipaparkan sebagai berikut:

1. Pendidikan, dari unsur pendidikan tidak ada uraian kegiatan yang dapat memanfaatkan aplikasi SLiMS.

2. Pengorganisasian dan Pendayagunaan Koleksi Bahan Pustaka/Sumber Informasi, uraian kegiatan yang dapat memanfaatkan aplikasi slim utuk mempermudah pekerkaan pustakawan terdapat pada kegiatan sebagai berikut :

A. Pengembangan Koleksi, adapun uraian kegiatan yang memanfaatkan aplikasi SLiMS pada pengembangan koleksi adalah :

1. Menyusun rencana operasional, pada sub unsur kegiatan ini butir kegiatan yang dapat memanfaatkan aplikasi SLiMS adalah kegiatan pengumpulan data yang akan digunakan untuk menyusun rencana operasional pengembangan koleksi. Hasil wawancara peneliti kepada pustakawan ${ }^{1}$ UPT Perpustakaan Institut Agama Islam Negeri Curup berkaitan dengan kegiatan ini bahwa kegiatan ini telah dilakukan. Petugas sebelum menyusun rencana operasional kegiatan koleksi akan mengumpulkan datadata yang terdapat pada data base aplikasi SLiMS berupa data daftar judul, jumlah eksemplar, data keterpakaian koleksi. Dimana data-data tersebut akan dijadikan salah satu acuan pengembangan koleksi. Adapun optimalisasi yang dapat dilakukan pustakawan dalam mencapai tujuan kegiatan adalah anjuran melaksanakan kegiatan yang belum dilakukan pustakawan, sementara kegiatan tersebut berperan penting. Atau memberikan saran memaksimalkan kegiatan yang telah dilakukan jika mungkin dilakukan lebih maksimal sehingga tujuan dari pengembangan koleksi dapat tercapai.

2. Melakukan survai minat pemakai, pada sub unsur kegiatan ini butir kegiatan yang dapat memanfaatkan aplikasi SLiMS adalah kegiatan pengumpulan data pada kegiatan survei minat pemakai dimana hasil survei akan dijadikan masukan pada pengembangan koleksi perpustakaan, sehingga hasil pengembangan koleksi sesuai dengan kebutuhan pengguna. Hasil wawancara peneliti kepada pustakawan ${ }^{2}$ UPT Perpustakaan Institut Agama Islam Negeri Curup sudah melakukan kegiatan ini. Dalam kegiatan ini

\footnotetext{
${ }^{1}$ Bapak Jr., pustakawan yang bertugas menyusun rencana operasional

${ }^{2}$ Bapak Jr., pustakawan yang bertugas survei minat pemakai
} 
petugas melakukan pengambilan data pada data base aplikasi SLiMS berupa data keterpakaian koleksi, koleksi yang sering digunakan, koleksi yang jarang dan tidak pernah digunakan pemustaka termasuk koleksi yang hilang.

Adapun optimalisasi yang dapat dilakukan pustakawan dalam mencapai tujuan kegiatan adalah anjuran melaksanakan kegiatan yang belum dilakukan pustakawan, sementara kegiatan tersebut berperan penting. Atau memberikan saran memaksimalkan kegiatan yang telah dilakukan jika mungkin dilakukan lebih maksimal sehingga tujuan dari pengembangan koleksi dapat tercapai.

3. Menyeleksi bahan pustaka, pada sub unsur kegiatan ini butir kegiatan yang dapat memanfaatkan aplikasi SLiMS adalah

- Melakukan survai bahan pustaka dengan mengumpulkan informasi bahan pustaka melalui data base SLiMS, dalam Kegiatan ini bukti fisik kegiatan ini adalah laporan. Adapun laporan yang dimaksud adalah informasi bahan pustaka berupa daftar judul, jumlah eksemplar, inventaris koleksi, data koleksi yang diminati dan status koleksi tertentu apakah merupakan kebutuhan pokok atau tambahan. Pustakawan melalui aplikasi SLiMS dapat menyelesaikan tugas ini. Tujuan kegiatan ini adalah untuk mengetahui ketersedian koleksi dan kebutuhan akan koleksi. Melalui hasil wawancara peneliti kepada pustakawan $^{3}$ UPT perpustakaan Institut Agama Islam Negeri Curup bahwa berkaitan dengan kegiatan ini telah dilakukan dengan mengumpulkan data yang telah tersedia dalam database aplikasi SLiMS, informasi yang dapat di ambil meliputi daftar judul buku yang paling diminati dan sebaliknya, daftar eksemplar, informasi ketersedian koleksi pokok atau penunjang.

Adapun optimalisasi yang dapat dilakukan pustakawan dalam mencapai tujuan kegiatan ini baik secara efisien maupun efektif adalah peningkatan kemampuan filter atau pengelompokan informasi dengan menggunakan aplikasi SLiMS serta manajemen dokumentasi data oleh pustakawan

${ }^{3}$ Ibu Ew., pustakawan yng bertugas menyeleksi bahan pustaka 
yang bertugas mengumpulkan data survey minat pemakai, sehingga hasil survey yang diperoleh benar-benar akurat.

- Meregistrasi bahan pustaka, pada butir kegiatan ini dapat memanfaatkan aplikasi SLiMS untuk meringankan tugas pustakawan. Kegiatan ini bertujuan untuk menginventaris bahan pustaka setelah diadakan, dari kegiatan ini akan diperoleh data bahan pustaka yang dimiliki sebuah perpustakaan. Melalui hasil wawancara peneliti kepada pustakawan ${ }^{4}$ UPT perpustakaan Institut Agama Islam Negeri Curup bahwa kegiatan meregistrasi bahan pustaka telah dilakukan secara rutin di UPT perpustakaan Institut Agama Islam Negeri Curup baik secara manual dengan menggunakan buku induk maupun secara elekronis dengan menggunakan aplikasi SLiMS. Kegiatan ini dilakukan untuk memudahkan pustakawan dalam pengembangan koleksi maupun untuk pengawasan koleksi.

Adapun optimalisasi yang dapat dilakukan pustakawan dalam mencapai tujuan kegiatan ini baik secara efisien maupun efektif adalah peningkatan kemampuan filter atau pengelompokan informasi dengan menggunakan aplikasi SLiMS serta manajemen dokumentasi data oleh pustakawan yang bertugas mengumpulkan data survey minat pemakai, sehingga hasil survey yang diperoleh benar-benar akurat.

- Menyeleksi bahan pustaka, pada butir kegiatan ini jugadapat memanfaatkan aplikasi SLiMS untuk meringankan tugas pustakawan. Proses seleksi dilakukan dengan mengidentifikasi bahan pustaka yang akan ditambahkan ke dalam koleksi perpustakaan, kegiatan seleksi bertujuan untuk menjaga mutu koleksi yang akan ditambahkan. Bahan pustaka yang akan diadakan dipilih secara cermat sesuai dengan kebutuhan pemustaka sesuai dengan kebijakan yang telah ditetapkan. Melalui hasil wawancara peneliti kepada pustakawan ${ }^{5}$ UPT perpustakaan Institut Agama Islam Negeri Curup bahwa berkaitan dengan kegiatan ini telah dilakukan dengan melakukan analisa database SLiMS mengenai informasi koleksi bahan pustaka yang akan diadakan akan tetapi belum

\footnotetext{
${ }^{4}$ Ibu Hs., pustakawan yang bertugas meregistrasi bahan pustaka

${ }^{5}$ Ibu ew., pustakawan yang bertugas menyeleksi bahan pustaka
} 
maksimal, serta belum tertibnya administrasi hasil kegiatan. Pustakawan melalui aplikasi SLiMS dapat menyelesaikan tugas ini sehingga tersedianya koleksi perpustakaan baik secara kualitatif maupun kuantitatif.

Adapun optimalisasi yang dapat dilakukan pustakawan dalam mencapai tujuan kegiatan ini baik secara efisien maupun efektif adalah peningkatan ketelitian, kecermatan dan konsisten pustakawan yang bertugas dalam menganalisa informasi yang tersedia dalam database SLiMS serta tertib administrasi hasil kegiatan seleksi.

4. Mengevaluasi dan menyiangi koleksi, pada subbagian kegiatan ini uraian kegiatan yang dapat memanfaatkan aplikasi SLiMS adalah kegiatan

- Mengidentifikasi bahan pustaka, untuk mempermudahkan pustakawan dalam melakukan tugas ini dapat memanfaatkan aplikasi SLiMS. Pustakawan yang ditugaskan melakukan kegiatan ini adalah Pustakawan Pertama dan Pustakawan Pelaksana Lanjutan. Tujuan kegiatan ini adalah terlaksananya identifikasi koleksi dengan menganalisa informasi koleksi yang ada pada data base aplikasi SLiMS. Akan tetapi identifikasi tidak hanya dilakukan dengan menganalisa data yang ada pada data base aplikasi tapi pustakawan juga melakukan identifikasi fisik bahan pustaka yang ada. Melalui hasil wawancara peneliti kepada pustakawan $^{6}$ UPT perpustakaan Institut Agama Islam Negeri Curup bahwa berkaitan dengan kegiatan ini telah dilakukan dengan memeriksa data base SLiMS, mengidentifikasi data koleksi perpustakaan yang masuk dalam kategori koleksi yang layak untuk disiangi. Kemudian mengubah informasi koleksi yang disiangi dalam database SLiMS, sehingga informasi koleksi sesuai dengan kondisi sebenarnya. Hanya saja belum tertib admistrasi dokumentasi hasil pelaksanaan kegiatan.

Adapun optimalisasi yang dapat dilakukan pustakawan UPT perpustakaan Institut Agama Islam Negeri Curup dalam mencapai tujuan kegiatan ini baik secara efisien maupun

\footnotetext{
${ }^{6}$ Ibu Sw., pustakawan yang bertugas mengidentifikasi bahan pustaka untuk penyiangan
} 
efektif adalah dengan memaksimalkan manajemen administrasi setiap kegiatan.

- Menetapkan hasil evaluasi dan penyiangan, pustakawan melalui aplikasi SLiMS dapat menyelesaikan tugas ini. Dari data hasil identifikasi yang telah dilakukan dengan menganalisa data base aplikasi slim maka selanjutnya penetapan hasil evaluasi dan penyiangan. Tujuan kegiatan ini adalah mendapatkan data koleksi hasil evaluasi dan penyiangan dengan menggnakan aplikasi SLiMS. Laporan hasil kegiatan tersebut tersedia pada aplikasi, sehingga memudahkan pustakawan dalam penyusunan laporan kegiatan evaluasi dan penyiangan. Melalui hasil wawancara peneliti kepada pustakawan ${ }^{7}$ UPT perpustakaan Institut Agama Islam Negeri Curup bahwa berkaitan dengan kegiatan ini telah dilakukan akan tetapi belum maksimal karena kurang tertibnya administrasi hasil kegiatan.

Adapun optimalisasi yang dapat dilakukan pustakawan UPT perpustakaan Institut Agama Islam Negeri Curup dalam mencapai tujuan kegiatan ini baik secara efisien maupun efektif adalah dengan memaksimalkan manajemen administrasi setiap kegiatan.

B. Pengolahan Bahan Pustaka

1. Menyusun rencana operasional, pada sub unsur kegiatan ini butir kegiatan yang dapat memanfaatkan aplikasi SLiMS adalah kegiatan pengumpulan data yang akan digunakan untuk menyusun rencana pengolahan bahan pustaka. Pengolahan merupakan salah satu kegiatan inti perpustakaan, koleksi yang baru diadakan wajib untuk diolah sebelum dilayankan untuk menjaga keamanan koleksi serta mempermuda proses temu kembali koleksi.

Hasil wawancara peneliti kepada pustakawan $^{8} \quad$ UPT Perpustakaan Institut Agama Islam Negeri Curup berkaitan dengan kegiatan ini bahwa kegiatan ini telah dilakukan. Petugas sebelum memulai tahapan pengolahan mengumpulkan data

\footnotetext{
${ }^{7}$ Ibu Sw., pustakawan yang bertugas menetapkan hasil evaluasi dan penyiangan

${ }^{8}$ Bapak Jr., pustakawan yang bertugas menyusun rencana operasional pengolahan bahan pustaka
} 
koleksi sebelumnya sebagai acuan untuk melanjutkan proses pengolahan buku selanjutnya.

Adapun optimalisasi yang dapat dilakukan pustakawan dalam mencapai tujuan kegiatan adalah anjuran melaksanakan kegiatan yang belum dilakukan pustakawan, sementara kegiatan tersebut berperan penting. Atau memberikan saran memaksimalkan kegiatan yang telah dilakukan jika mungkin dilakukan lebih maksimal sehingga tujuan dari pengembangan koleksi dapat tercapai.

2. Melakukan verifikasi data bibliografi, uraian kegiatan ini meliputi melakukan verifikasi data bibliografi dengan menggunakan katalog yang ada pada aplikasi SLiMS sebagai acuan untuk mengetahui keberadaan koleksi untuk subjek dan media tertentu.

Hasil wawancara peneliti kepada pustakawan $^{9}$ UPT Perpustakaan Institut Agama Islam Negeri Curup berkaitan dengan kegiatan ini bahwa kegiatan ini telah dilakukan. Petugas sebelum memulai tahapan pengolahan mengumpulkan data koleksi sebelumnya sebagai acuan untuk melanjutkan proses pengolahan buku selanjutnya.

Adapun optimalisasi yang dapat dilakukan pustakawan dalam mencapai tujuan kegiatan adalah anjuran melaksanakan kegiatan yang belum dilakukan pustakawan, sementara kegiatan tersebut berperan penting. Atau memberikan saran memaksimalkan kegiatan yang telah dilakukan jika mungkin dilakukan lebih maksimal sehingga tujuan dari pengembangan koleksi dapat tercapai.

3. Melakukan katalogisasi, merupakan kegiatan membuat wakil ringkas koleksi yang dimiliki oleh sebuah perpustakan, yang bertujuan membantu pengguna dalam temu kembali koleksi. Butir kekegiatan ini dapat memanfaatkan aplikasi SLiMS bagi perpustakaan yang telah terotomasi.

- Katalog sederhana adalah melakukan katalogisasi sederhana dalam kegiatan pengolahan bahan pustaka; bukti fisik kegiatan ini adalah daftar judul yang tertuang dalam katalog sederhana. Pustakawan yang ditugaskan melakukan kegiatan

\footnotetext{
${ }^{9}$ Ibu Sw., pustakawan yang bertugas melakukan verifikasi data bibliografi
} 
ini adalah pustakawan pertama dan pustakawan pelaksana lanjutan.

Melalui hasil wawancara peneliti kepada pustakawan ${ }^{10}$ UPT perpustakaan Institut Agama Islam Negeri Curup bahwa berkaitan dengan kegiatan ini telah dilakukan hanya saja masih terjadi sistem pencatatan tanda baca yang tidak sesuai.

Adapun optimalisasi yang dapat dilakukan pustakawan dalam mencapai tujuan kegiatan ini baik secara efisien maupun efektif adalah kembali melakukan pencatatan dengan baik.

- Katalog kompleks pengolahan bahan pustaka; bukti fisik kegiatan ini adalah daftar judul yang tertuang dalam katalog kompleks. Pustakawan yang ditugaskan melakukan kegiatan ini adalah Pustakawan Pertama dan Pustakawan Pelaksana Lanjutan. Melalui hasil wawancara peneliti kepada pustakawan $^{11}$ UPT perpustakaan Institut Agama Islam Negeri Curup bahwa berkaitan dengan kegiatan ini telah sebagin telah dilakukan akan tetapi masih menerapkan yang sederhana.

Adapun optimalisasi yang dapat dilakukan pustakawan dalam mencapai tujuan kegiatan ini baik secara efisien maupun efektif adalah berusaha mencatat katalog yang kompleks.

4. Menentukan tajuk subyek kegiatan pengolahan bahan pustaka; bukti fisik kegiatan ini adalah daftar judul koleksi dengan Tajuk Subyek yang dibuat. Pustakawan yang ditugaskan melakukan kegiatan ini adalah Pustakawan Pertama dan Pustakawan Pelaksana Lanjutan. Pustakawan melalui aplikasi SLiMS dapat menyelesaikan tugas ini. Tujuan kegiatan ini adalah menentukan tajuk atau isi, topik sesuai dengan kosa kata atau istilah yang tercantum dalam daftar tajuk yang nantinya tajuk asubjek akan menjadi titik akses dalam penelusuran informasi bagi pemustaka.

\footnotetext{
${ }^{10}$ Ibu Sw., pustakawan yang bertugas melakukan Katalog sederhana

${ }^{11}$ Ibu Ew., pustakawan yang bertugas melakukan katalog kompleks
} 
Melalui hasil wawancara peneliti kepada pustakawan $^{12}$ UPT perpustakaan Institut Agama Islam Negeri Curup bahwa berkaitan dengan kegiatan ini telah dilakukan dalam pengelolaan.

Adapun optimalisasi yang dapat dilakukan pustakawan dalam mencapai tujuan kegiatan ini baik secara efisien maupun efektif adalah memilih tajuk yang sesuai dengan daftar tajuk yang digunakan perpustakaan sehingga dalam proses penelusuran dan kerja sama SLiMS dapat menjadi acuan.

5. Mengklasifikasi yang bersifat sederhana atau penentuan notasi utama tanpa notasi tambahan dalam Kegiatan pengolahan bahan pustaka; bukti fisik kegiatan ini adalah daftar judul koleksi dengan klasifikasi sederhana yang dibuat. Pustakawan yang ditugaskan melakukan kegiatan ini adalah Pustakawan Pertama dan Pustakawan Pelaksana Lanjutan. Pustakawan melalui aplikasi SLiMS dapat menyelesaikan tugas ini. Tujuan kegiatan ini adalah menentukan notasi utama sebuah koleksi tanpa notasi tambahan untuk mempermuda petugas dalam mengelola koleksi maupun mempermuda penggunaan memanfaatkan koleksi yang dimiliki sebuah perpustakaan. Melalui hasil wawancara peneliti kepada pustakawan ${ }^{13}$ UPT perpustakaan Institut Agama Islam Negeri Curup bahwa berkaitan dengan kegiatan ini telah dilakukan.

Adapun optimalisasi yang dapat dilakukan pustakawan UPT perpustakaan dalam mencapai tujuan kegiatan ini baik secara efisien maupun efektif adalah melakukan evaluasi hasil klasifikasi menggunakan data aplikasi.

6. Melakukan klasifikasi yang bersifat kompleks dalam kegiatan pengolahan bahan pustaka; bukti fisik kegiatan ini adalah daftar judul koleksi dengan klasifikasi kompleks yang dibuat. Pustakawan yang ditugaskan melakukan kegiatan ini adalah Pustakawan Pertama dan Pustakawan Pelaksana Lanjutan. Pustakawan melalui aplikasi SLiMS dapat menyelesaikan tugas ini. Tujuan kegiatan ini adalah menentukan notasi kelas utama disertai dengan notasi tambahan yang lebih spesifik untuk mempermuda petugas dalam mengelola koleksi maupun

\footnotetext{
${ }^{12}$ Bapak Jr., pustakawan yang bertugas menentukan tajuk subyek

${ }^{13} \mathrm{Ibu}$ Sw., pustakawan yang bertugas melakukan Klasifikasi sederhana
} 
mempermuda penggunaan memanfaatkan koleksi yang dimiliki sebuah perpustakaan. Melalui hasil wawancara peneliti kepada pustakawan Institut Agama Islam Negeri Curup bahwa berkaitan dengan kegiatan ini telah dilakukan namun masih cenderung bersifat sederhana.

Adapun optimalisasi yang dapat dilakukan pustakawan UPT perpustakaan dalam mencapai tujuan kegiatan ini baik secara efisien maupun efektif adalah semaksimal mungkin gunakan klasifikasi yang kompleks sehingga terkumpul kajian yang lebih spesifik. Hal ini dapat dievaluasi melalui data pada aplikasi.

7. Menentukan kata kunci dalam kegiatan pengolahan bahan pustaka; bukti fisik kegiatan ini adalah daftar kata kunci yang dibuat. Pustakawan yang ditugaskan melakukan kegiatan ini adalah Pustakawan Pertama dan Pustakawan Pelaksana Lanjutan. Pustakawan melalui aplikasi SLiMS dapat menyelesaikan tugas ini. Tujuan kegiatan ini adalah membuat konsep-konsep inti yang di bahas dalam sebuah koleksi/karya sehingga memudahkan pengunjung untuk memahami isi dari koleksi tersebut serta pembuatan kata kunci juga membantu mempermuda dalam penelusuran koleksi perpustakaan. Melalui hasil wawancara peneliti kepada pustakawan $^{14}$ UPT perpustakaan Institut Agama Islam Negeri Curup bahwa berkaitan dengan kegiatan ini telah dilakukan dalam proses pengolahan koleksi yaitu pada saat menginput data bibliografi koleksi pada aplikasi SLiMS pustakawan yang bertugas wajib memasukkan kata kunci koleksi.

Adapun optimalisasi yang dapat dilakukan pustakawan UPT perpustakaan dalam mencapai tujuan kegiatan ini baik secara efisien maupun efektif adalah benar-benar membuat kata kunci sesuai dengan inti pembahasan dari sebuah koleksi.

8. Membuat anotasi dalam kegiatan Pengolahan Bahan Pustaka; bukti fisik kegiatan ini adalah daftar judul koleksi dengan anotasi yang dibuat. Pustakawan yang ditugaskan melakukan kegiatan ini adalah Pustakawan Pertama dan Pustakawan Pelaksana Lanjutan. Pustakawan melalui aplikasi SLiMS dapat menyelesaikan tugas ini. Tujuan kegiatan ini adalah membuat

${ }^{14}$ Ibu Ew., pustakawan yang bertugas membuatkata kunci 
gambaran singkat atau ringkas isi dari bahan pustaka. Melalui hasil wawancara peneliti kepada pustakawan $^{15}$ UPT perpustakaan Institut Agama Islam Negeri Curup bahwa berkaitan dengan kegiatan ini telah dilakukan dengan menambahkan anotasi pada saat pengolahan sebuah bahan pustaka, aplikasi slim telah dilengkapi kolom catatan untuk membuat anotasi, sehingga pada tampilan opac muncul setiap anotasi koleksi yang dibuat, yang dapat membantu pemustaka mengetahui isi dari pembahasan koleksi secara ringkas. Akan tetapi belum semua anotasi koleksi dibuat.

9. Mengalihkan data bibliografi dalam kegiatan pengolahan bahan Pustaka; bukti fisik kegiatan ini adalah daftar cantuman data bibliografi yang dialihkan. Pustakawan yang ditugaskan melakukan kegiatan ini adalah Pustakawan Pertama dan Pustakawan Pelaksana Lanjutan. Pustakawan melalui aplikasi SLiMS dapat menyelesaikan tugas ini. Tujuan kegiatan ini adalah memasukkan data bibliografi koleksi ke dalam aplikasi SLiMS sebelum dilayankan. Melalui hasil wawancara peneliti kepada pustakawan ${ }^{16}$ Institut Agama Islam Negeri Curup bahwa berkaitan dengan kegiatan ini telah dilakukan secara kontinyu oleh pustakawan dengan karena pada perpustakaan IAIN Curup dikarenakan telah terotomasi maka semua data koleksi telah dialihkan menjadi data elektronis. Hanya saja masih beberapa kolom data bibliografi tidak diisi lengkap.

Adapun optimalisasi yang dapat dilakukan pustakawan UPT perpustakaan dalam mencapai tujuan kegiatan ini baik secara efisien maupun efektif adalah pustakawan yang bertugas lebih teliti dan lebih lengkap dalam mengiputan data bibliografi.

10. Menyunting data bibliografi dalam kegiatan pengolahan bahan Pustaka; bukti fisik kegiatan ini adalah daftar cantuman data bibliografi yang disunting. Pustakawan yang ditugaskan melakukan kegiatan ini adalah Pustakawan Pertama dan Pustakawan Pelaksana Lanjutan. Pustakawan melalui aplikasi SLiMS dapat menyelesaikan tugas ini. Tujuan kegiatan ini adalah memeriksa kebenaran deskripsi sebuat bahan pustaka berdasarka acuan tertentu. Bukti fisik: Daftar data bibliografi

\footnotetext{
${ }^{15}$ Ibu Ew., pustakawan yang bertugas membuat anotasi

${ }^{16}$ Ibu Sw., pustakawan yang bertugas mengalihkan data bibliografi
} 
memuat informasi: judul, edisi, data khusus, tempat terbit, penerbit, tahun terbit, deskripsi fisik, seri, catatan, nomor standar, dan keterangan hasil penyuntingan. Melalui hasil wawancara peneliti kepada pustakawan ${ }^{17}$ UPT perpustakaan Institut Agama Islam Negeri Curup bahwa berkaitan dengan kegiatan ini telah dilakukan secara kontinyu oleh pustakawan dengan memeriksa data base aplikasi SLiMS, dan memperbaiki jikalau ada data bibliografi yang belum sesuai sengan acuan/standar untuk memastikan ketepatan data koleksi.

Adapun optimalisasi yang dapat dilakukan pustakawan UPT perpustakaan dalam mencapai tujuan kegiatan ini baik secara efisien maupun efektif adalah lebih konsisten dan cermat dalam melakukan penyunting data bibliografi.

\section{Mengelola data bibliografi}

- Dalam bentuk kartu katalog, untuk perpustakaan yang telah menggunakan aplikasi SLiMS kegiatan pembuatan kartu katalog dapat dilakukan otomatis atau dapat langsung dicetak karena aplikasi SLiMS telah menyediakan fitur tersebut. Tujuan kegiatan ini adalah membuat kartu katalog yang dapat membantu mempermuda temu kembali koleksi. Melalui hasil wawancara peneliti kepada pustakawan ${ }^{18}$ UPT perpustakaan Institut Agama Islam Negeri Curup bahwa berkaitan dengan kegiatan ini belum dilakukan secara kontinyu dikarenakan sekarang kartu katalog jarang digunakan pemustaka untuk mencari koleksi, hanya untuk kelengkapan administrasi perpustakaan.

Adapun optimalisasi yang dapat dilakukan pustakawan dalam mencapai tujuan kegiatan ini baik secara efisien maupun efektif adalah pustakawan hendaknya melakukan tugas ini dengan rutin, apabila katalog elektronik/opac tidak dapat difungsikan ada alternative katalog kartu.

- Dalam bentuk basis data dalam kegiatan pengolahan bahan pustaka; bukti fisik kegiatan ini adalah daftar file data bibliografi yang dibuat. Pustakawan yang ditugaskan melakukan kegiatan ini adalah Pustakawan Pertama dan

\footnotetext{
${ }^{17}$ Ibu Sw., pustakawan yang bertugas menyunting data bibliografi

${ }^{18}$ Ibu Hs., pustakawan yang bertugas membuat kartu katalog
} 
Pustakawan Pelaksana Lanjutan. Pustakawan melalui aplikasi SLiMS dapat menyelesaikan tugas ini. Tujuan kegiatan ini adalah memelihara cantuman data pada data base aplikasi SLiMS, dengan cara melakukan backup data data base, update aplikasi, serta indexing atau inverting. Melalui hasil wawancara peneliti kepada pustakawan ${ }^{19}$ UPT perpustakaan Institut Agama Islam Negeri Curup bahwa berkaitan dengan kegiatan ini telah dilakukan hanya saja dalam pelaksanaannya belum maksimal dikarenakan belum teratur dalam pengarsipan basis data yang telah dicetak.

12. Membuat kelengkapan pustaka dalam kegiatan pengolahan bahan pustaka; bukti fisik kegiatan ini adalah daftar koleksi yang dibuatkan kelengkapan pustakanya. Pustakawan yang ditugaskan melakukan kegiatan ini adalah Pustakawan Pertama dan Pustakawan Pelaksana Lanjutan. Pustakawan melalui aplikasi SLiMS dapat menyelesaikan tugas ini, pada aplikasi ini telah terdapat fitur pembuatan kelengkapan pustaka seperti nomor punggung, barcode. Tujuan kegiatan ini adalah mebuat identitas koleksi sehingga koleksi dengan mudah ditemukan. Melalui hasil wawancara peneliti kepada pustakawan ${ }^{20}$ UPT perpustakaan Institut Agama Islam Negeri Curup bahwa berkaitan dengan kegiatan ini telah dilakukan hanya saja tidak semua kelengkapan pustaka datap dibuat oleh aplikasi SLiMS.

Adapun optimalisasi yang dapat dilakukan pustakawan dalam mencapai tujuan kegiatan ini baik secara efisien maupun efektif adalah pustakawan yang bertugas lebih teliti dan rapi dalam membuat kelengkapan pustaka.

13. Membuat sari karangan indikatif, dalam kegiatan pengolahan bahan pustaka; bukti fisik kegiatan ini adalah daftar judul koleksi yang dibuatkan sari karangan indikatif. Pustakawan yang ditugaskan melakukan kegiatan ini adalah Pustakawan Pertama dan Pustakawan Pelaksana Lanjutan. Pustakawan melalui aplikasi SLiMS dapat menyelesaikan tugas ini, karena fiturnya telah disediakan. Tujuan kegiatan ini adalah dengan adanya sari karangan pada setiap koleksi perpustakaan, dapat

${ }^{19}$ Ibu Ew., pustakawan yang bertugas mengelola basis data

${ }^{20}$ Ibu Hs., pustakawan yang bertugas membuat kelengkapan pustaka 
membantu pemustaka mengetahui isi buku tanpa membuka bukunya. Melalui hasil wawancara peneliti kepada pustakawan $^{21}$ UPT perpustakaan Institut Agama Islam Negeri Curup bahwa berkaitan dengan kegiatan ini telah dilakukan hanya saja belum semua koleksi di buat sari karangannya.

Adapun optimalisasi yang dapat dilakukan pustakawan UPT perpustakaan dalam mencapai tujuan kegiatan ini baik secara efisien maupun efektif adalah pustakawan hendaknya membuat semua sari karangan dari koleksi yang dimiliki.

14. Membuat sari karangan informative dalam kegiatan pengolahan bahan pustaka; bukti fisik kegiatan ini adalah daftar judul koleksi yang dibuatkan sari karangan informatif. Pustakawan yang ditugaskan melakukan kegiatan ini adalah Pustakawan Pertama dan Pustakawan Pelaksana Lanjutan. Pustakawan melalui aplikasi SLiMS dapat menyelesaikan tugas ini. Tujuan kegiatan ini adalah dengan adanya sari karangan atau uraian singkat tetapi akurat pada setiap koleksi perpustakaan, dapat membantu pemustaka mengetahui isi buku tanpa membuka bukunya. Melalui hasil wawancara peneliti kepada pustakawan $^{22}$ Institut Agama Islam Negeri Curup bahwa berkaitan dengan kegiatan ini telah dilakukan hanya saja belum sari karangan yang dibuat.

Adapun optimalisasi yang dapat dilakukan pustakawan UPT perpustakaan dalam mencapai tujuan kegiatan ini baik secara efisien maupun efektif adalah hendaknya pustakawan segera membuat semua sari karangan koleksi pada aplikasi SLiMS.

C. Penyimpanan dan pelestarian bahan pustaka

1. Menyusun rencana operasional

- Mengumpulkan data, pada sub unsur kegiatan ini butir kegiatan yang dapat memanfaatkan aplikasi SLiMS adalah kegiatan pengumpulan data yang akan digunakan untuk menyusun rencana operasional Penyimpanan dan pelestarian bahan pustaka.

\footnotetext{
${ }^{21}$ Ibu Ew., pustakawan yang bertugas membuat sari karangan indikatif

${ }^{22}$ Ibu Ew., pustakawan yang bertugas membuat sari karangan informative
} 
Hasil wawancara peneliti kepada pustakawan $^{23}$ UPT Perpustakaan Institut Agama Islam Negeri Curup berkaitan dengan kegiatan ini bahwa kegiatan ini telah dilakukan. Petugas sebelum menyusun rencana operasional kegiatan penyimpanan dan pelestarian bahan pustakaakan mengumpulkan data-data yang terdapat pada data base aplikasi SLiMS berupa data daftar judul, jumlah eksemplar, data keterpakaian koleksi. Dimana data-data tersebut akan dijadikan salah satu acuan pengembangan koleksi.

Adapun optimalisasi yang dapat dilakukan pustakawan dalam mencapai tujuan kegiatan adalah anjuran melaksanakan kegiatan yang belum dilakukan pustakawan, sementara kegiatan tersebut berperan penting. Atau memberikan saran memaksimalkan kegiatan yang telah dilakukan jika mungkin dilakukan lebih maksimal sehingga tujuan dari penyimpanan dan pelestarian bahan pustakadapat tercapai.

D. Pelayanan Informasi

1. Menyusun rencana operasional

- Mengumpulkan data, pada sub unsur kegiatan ini butir kegiatan yang dapat memanfaatkan aplikasi SLiMS adalah kegiatan pengumpulan data yang akan digunakan untuk menyusun rencana operasional Penyimpanan dan pelestarian bahan pustaka.

Hasil wawancara peneliti kepada pustakawan ${ }^{24}$ UPT Perpustakaan Institut Agama Islam Negeri Curup berkaitan dengan kegiatan ini bahwa kegiatan ini telah dilakukan. Petugas sebelum menyusun rencana operasional kegiatan pelayanan informasi pustakaakan mengumpulkan data-data yang terdapat pada data base aplikasi SLiMS berupa laporan koleksi, keterpakaian koleksi dan pengunjung.

Adapun optimalisasi yang dapat dilakukan pustakawan dalam mencapai tujuan kegiatan adalah anjuran melaksanakan kegiatan yang belum dilakukan pustakawan,

\footnotetext{
${ }^{23}$ Ibu Sw., pustakawan yang bertugas menyusun rencana operasional penyimpanan dan pelestarian bahan pustaka

${ }^{24} \mathrm{Ibu} \mathrm{Sw}$., pustakawan yang bertugas menyusun rencana operasional pelayanan informasi
} 
sementara kegiatan tersebut berperan penting. Atau memberikan saran memaksimalkan kegiatan yang telah dilakukan jika mungkin dilakukan lebih maksimal sehingga tujuan dari penyimpanan dan pelestarian bahan pustakadapat tercapai.

2. Melakukan layanan sirkulasi, dalam kegiatan pelayanan informasi, bukti fisik kegiatan ini adalah daftar judul koleksi yang dilayankan. Pustakawan yang ditugaskan melakukan kegiatan ini adalah Pustakawan Pertama dan Pustakawan Pelaksana Lanjutan. Pustakawan melalui aplikasi SLiMS dapat menyelesaikan tugas ini. Tujuan kegiatan ini adalah memberikan pelayanan peminjaman, pengembalian dan perpanjangan waktu pinjaman kepada pemustaka.

Melalui hasil wawancara peneliti kepada pustakawan ${ }^{25}$ UPT perpustakaan Institut Agama Islam Negeri Curup bahwa berkaitan dengan kegiatan ini telah dilakukan. Dikarenakan perpustakaan IAIN Curup telah terotomasi sehingga system layanan sirkulasi telah dilakukan secara elektronik, dengan menggunakan aplikasi SLiMS. Hanya saja belum tertib administrasi laporan yang dapat digunakan untuk evaluasi layanan.

Adapun optimalisasi yang dapat dilakukan pustakawan dalam mencapai tujuan kegiatan ini baik secara efisien maupun efektif adalah semua petuas sirkulasi untuk lebih tertib adminstarasi.

3. Melakukan layanan rujukan

- Melakukan penelusuran literatur, butir kegiatan ini dapat memanfaatkan aplikasi SLiMS untuk mempermuda pekerjaan pustakawan. Penelusuran literature atau kegiatan menemukan kembali informasi akan lebih muda dengan menggunakan fitur pencarian opac yang telah disediakan aplikasi SLiMS. Tujuan kegiatan ini untuk mendukung penelitian, penulisan ilmiah, pencarian bahan bacaan yang dibutuhkan untuk penelitian atau penuliasan ilmiah. Tujuan penelusuran literatur untuk mendukung penelitian dan atau penulisan ilmiah, serta bahan bacaan sesuai kebutuhan

${ }^{25}$ Ibu Sw., pustakawan yang bertugas melakukan layanan sirkulasi 
pengguna perpustakaan Untuk peneliti dan atau penulisan ilmiah.

4. Melakukan bimbingan pemakai perpustakaan, butir kegiatan ini juga dapat dilakukan dengan memanfaatkan aplikasi SLiMS. Pustakawan dapat melakukan bimbingan temu kembali koleksi kepada pemustaka yang belum dapat mencari koleksi yang dibutuhkan secara cepat, muda dan tepat dengan memanfaatkan fitur opac yang di sediakan aplikasi slim yang dapat mempermuda pemustaka dalam temu kembali koleksi.

Melalui hasil wawancara peneliti kepada pustakawan ${ }^{26}$ UPT perpustakaan Institut Agama Islam Negeri Curup bahwa berkaitan dengan kegiatan ini telah dilakukan oleh pustakawan untuk membantu pemustaka dalam melakukan temu kembali koleksi sehingga mereka dapat dengan maksimalkan memanfaatkan sumber informasi yang disediakan untuk menunjang kegiatan belajar mengajar.

5. Membuat analisis kepustakaan

- Mengumpulkan data, pada sub unsur kegiatan ini butir kegiatan yang dapat memanfaatkan aplikasi SLiMS adalah kegiatan pengumpulan data yang akan digunakan untuk membuat analisis kepustakaan.

Hasil wawancara peneliti kepada pustakawan $^{27}$ UPT Perpustakaan Institut Agama Islam Negeri Curup berkaitan dengan kegiatan ini bahwa kegiatan ini telah dilakukan. Petugas sebelum menyusun rencana operasional kegiatan analisis kepustakaan mengumpulkan data-data yang terdapat pada data base aplikasi SLiMS.

Adapun optimalisasi yang dapat dilakukan pustakawan dalam mencapai tujuan kegiatan adalah anjuran melaksanakan kegiatan yang belum dilakukan pustakawan, sementara kegiatan tersebut berperan penting. Atau memberikan saran memaksimalkan kegiatan yang telah dilakukan jika mungkin dilakukan lebih maksimal sehingga tujuan analisis kepustakaan.

\footnotetext{
${ }^{26} \mathrm{Ibu}$ Sw., pustakawan yang bertugas melakukan bimbingan pemakai

${ }^{27}$ Ibu Ew., pustakawan yang bertugas membuat analisis kepustakaan
} 


\section{Statistik}

- Mengumpul data Statistik, bukti fisik kegiatan ini adalah laporan data statistik koleksi yang dibuat. Dapat berupa data mengenai koleksi, pengunjung, peminjam, pemustaka dll. Pustakawan yang ditugaskan melakukan kegiatan ini adalah Pustakawan Pertama dan Pustakawan Pelaksana Lanjutan. Pustakawan melalui aplikasi SLiMS dapat menyelesaikan tugas ini. Tujuan kegiatan ini adalah mengumpulkan data-data perpustakaan mengenai koleksi, pengunjung, peminjam, pemustaka dll.Melalui hasil wawancara peneliti kepada pustakawan ${ }^{28}$ UPT perpustakaan Institut Agama Islam Negeri Curup bahwa berkaitan dengan kegiatan ini telah dilakukan.

Adapun optimalisasi yang dapat dilakukan pustakawan dalam mencapai tujuan kegiatan ini baik secara efisien maupun efektif adalah pustakawan yang bertugas lebih teliti, cermat serta tertib administrasi.

- Mengolah dan Menyusun Data Statistik, bukti fisik kegiatan ini adalah laporan data statistik koleksi yang telah diolah dan disusun bias berbentuk table, grafik, atau diagram.

Pustakawan yang ditugaskan melakukan kegiatan ini adalah Pustakawan Pertama dan Pustakawan Pelaksana Lanjutan. Pustakawan melalui aplikasi SLiMS dapat menyelesaikan tugas ini. Tujuan kegiatan ini adalah mengumpulkan, menyusun dan menyajikan data-data perpustakaan mengenai koleksi, pengunjung, peminjam, pemustaka dan lain-lain. Melalui hasil wawancara peneliti kepada pustakawan $^{29}$ UPT perpustakaan Institut Agama Islam Negeri Curup bahwa berkaitan dengan kegiatan ini telah dilakukan.

Adapun optimalisasi yang dapat dilakukan pustakawan dalam mencapai tujuan kegiatan ini baik secara efisien maupun efektif adalah pustakawan yang bertugas lebih teliti, cermat serta tertib administrasi.

\footnotetext{
${ }^{28}$ Ibu Hs., pustakawan yang bertugas mengumpul data Statistik

${ }^{29}$ Ibu Hs., pustakawan yang bertugas mengolah dan menyusun data statistik
} 
7. Pengkajian pengembangan perpustakan, dokumentasi dan informasi

- Menyusun rencana operasional

Mengumpul data untuk menyusun rencana operasonal, bukti fisik kegiatan ini adalah laporan data statistik koleksi yang dibuat. Dapat berupa data mengenai koleksi, pengunjung, peminjam, pemustaka dll. Pustakawan yang ditugaskan melakukan kegiatan ini adalah Pustakawan Pertama dan Pustakawan Pelaksana Lanjutan. Pustakawan melalui aplikasi SLiMS dapat menyelesaikan tugas ini. Tujuan kegiatan ini adalah mengumpulkan data-data perpustakaan mengenai koleksi, pengunjung, peminjam, pemustaka dll ayang digunakan dalam pengkajian pengembangan perpustakan, dokumentasi dan informasi.

Melalui hasil wawancara peneliti kepada pustakawan ${ }^{30}$ UPT perpustakaan Institut Agama Islam Negeri Curup bahwa berkaitan dengan kegiatan ini telah dilakukan.

Adapun optimalisasi yang dapat dilakukan pustakawan dalam mencapai tujuan kegiatan ini baik secara efisien maupun efektif adalah pustakawan yang bertugas lebih teliti, cermat serta tertib administrasi.

8. Melakukan pengkajian

- Mengumpul data untuk pengkajian yang bersifat sederhana dan Mengumpul data untuk pengkajian yang bersifat kompleks. Mengumpul data untuk melakukan pengkajian. Dapat berupa data mengenai koleksi, pengunjung, peminjam, pemustaka dll. Pustakawan yang ditugaskan melakukan kegiatan ini adalah semua jenjang pustakawan. Pustakawan melalui aplikasi SLiMS dapat menyelesaikan tugas ini. Tujuan kegiatan ini adalah mengumpulkan datadata perpustakaan mengenai koleksi, pengunjung, peminjam, pemustaka dll ayang digunakan dalam pengkajian pengembangan perpustakan, dokumentasi dan informasi untuk dipergunakan dalam menyusun pengkajian.

30 Ibu Hs., pustakawan yang bertugas menyusun rencana operasional Pengkajian pengembangan perpustakan, dokumentasi dan informasi 
Melalui hasil wawancara peneliti kepada pustakawan ${ }^{31}$ UPT perpustakaan Institut Agama Islam Negeri Curup bahwa berkaitan dengan kegiatan ini telah dilakukan.

Adapun optimalisasi yang dapat dilakukan pustakawan dalam mencapai tujuan kegiatan ini baik secara efisien maupun efektif adalah pustakawan yang bertugas lebih teliti, cermat serta tertib administrasi dalam pengumpulan data.

\section{KESIMPULAN}

Dapat disimpulkan bahwa pemanfaatan aplikasi SLiMS di perpustakaan Institut Agama Islam Negeri Curup dirasakan masih belum optimal karena Pustakawan yang ada masih terbatas mengerjakan tugastugas pokok mereka. Pustakawan hendaknya meningkatkan kemampuan mereka dalam memanfaat aplikasi SLiMS dengan menambah pengetahuan serta keterampilan mengenai aplikasi SLiMS serta meningkatkan skill pengoperasian perangkat komputer. Sehingga kinerja pada Perpustakaan Institut Agama Islam Negeri Curup dapat ditingkatkan.

\section{DAFTAR RUJUKAN}

Indonesia. (2007). Undang-undangTentangPerpustakaan. UU no. 43Tahun 2007, TLN No. 4774 (1991). PengantarIlmuPerpustakaan. Jakarta: Gramedia.

Ridho, M. Rasyid. (2012). Senayan Library Management System for dummies. Jakarta: SDC.

https://iffatunnavisah.blogspot.com/2015/11/makalah-perpustakaan-profesipustakawan.html

Wikipedia. (2018, Agustus 9). Senayan (perangkat lunak). Retrieved September 11, 2018, from Wikipedia: https://id.wikipedia.org/wiki/Senayan_(perangkat_lunak)

OnnyCahyo Widodo. (2016). Efektifitaspenggunaan software open source (SLiMS) pada perpustakaanperguruantinggi di malang.Skripsi. Malang: UniversitasAirlangga

Rex Fritz Sidupa. (2016). PengukuranKinerjaAplikasiSLiMS pada PelayananTeknologiInformasiMenggunakan Framework ITIL v.3 (StudiKasus: Perpustakaan dan Arsip Daerah Kota Salatiga).Skripsi. Salatiga: Universitas Kristen Satya WacanaSalatiga

\footnotetext{
${ }^{31} \mathrm{Ibu}$ Ew., pustakawan yang bertugas melakukan pengkajian
} 